\title{
Political-Economy and Governance Issues in the Indian Economic Reform Process
}

\section{Pranab K. Bardhan}

I am grateful to ASARC for the invitation to deliver the 2003 Narayanan Oration and am happy to be here at The Australian National University. I do not know ex-President Narayanan personally but we have a good common friend (K N Raj) from whom I had often heard glowing accounts about Dr Narayanan. Exactly 20 years back I gave the Radhakrishnan Lecture ${ }^{1}$ at Oxford University, and I now have great pleasure in getting this opportunity to honour another distinguished south Indian ex-President.

My subject today is political economy and governance issues in Indian economic reform. Political economy is concerned with distribution of economic and political power, and inequality in this distribution poses important questions in a democracy. In 1949, as the Indian Constitution was getting ready and the debates in the Constituent Assembly were being wound up, B.R Ambedkar, a founding father of the Indian Constitution, said in a speech in that Assembly:

On the 26th of January, we are going to enter a life of contradictions. In politics we will have equality and in social and economic life, we will have inequality ... How long shall we continue to live this life of contradictions?

More than 50 years later in India we still live this life of contradictions, although there have been many changes, some of which would even have taken Ambedkar by surprise.

I will start with some historical and social factors which provide the context for Indian democracy and have shaped its complex unfolding in the last five decades, and then relate these to the various disjunctures between economics and politics that have developed in the on-going economic reform process in the last decade or so.

The historical origins of democracy in India are sharply different from those in much of the west, and these differences are reflected in the current functioning of democracy in India, making it difficult to match the Indian case to the canonical cases in the usual theories of democracy. At least five of these differences are: 
1. While in Europe democratic rights were won over continuous battles against aristocratic privileges and arbitrary powers of absolute monarchs, in India these battles were fought by a coalition of groups in an otherwise fractured society against the colonial masters. Even though part of the freedom struggle was associated with on-going social movements to win land rights for peasants against the landed oligarchy, the dominant theme was to fight colonialism. And in this fight, particularly under the leadership of Gandhi, disparate groups were forged together to fight a common external enemy, and this required strenuous methods of consensus-building and conflict management (rather than resolution) through co-opting dissent and selective buyouts. Long before Independence the Congress Party operated on consensual rather than majoritarian principles. The various methods of group bargaining and subsidies and 'reservations' for different social end economic categories that are common practice in India today can be traced to this earlier history.

2. Unlike in western Europe democracy came to India before any substantial industrial transformation of a predominantly rural economy, and before literacy was widespread. This seriously influenced the modes of political organization and mobilization, the nature of political discourse, and the excessive economic demands on the state. Democratic (and redistributive) aspirations of newly mobilized groups outstripped the surplus-generating capacity of the economy, demand overloads sometimes even short-circuiting the surplus generation process itself,

3. In western history the power of the state was gradually hemmed in by civil society dense with interest-based associations. In India groups are based more on ethnic and other identities (caste, religion, language, etc.), although the exigencies of electoral politics have somewhat reshaped the boundaries of (and ways of aggregating) these identity groups. This has meant a much larger emphasis on group rights than on individual rights. ${ }^{2}$ A perceived slight of a particular group (in, say, the speech or behaviour of a political leader from another group) usually causes much more of a public uproar than crass violations of individual civil rights even when many people across different groups are to suffer from the latter. The issues that catch public imagination are the group demands for preferential treatment (like reservation of public-sector jobs) and protection against ill-treatment. This is not surprising in a country where the self-assertion of hitherto subordinate groups in a hierarchical society takes primarily the form of a quest for group dignity and protected group-niches in public jobs.

4. In western history expansion of democracy gradually limited the power of the state. In India, on the other hand, democratic expansion has often meant an increase in the power of the state. The subordinate groups often appeal to the state for protection and relief. With the decline of hierarchical author- 
ity in the villages and with the moral and political environment of age-old deference to community norms changing, the state has moved into the institutional vacuum thus left in the social space. For example, shortly after Independence popular demands of land reform legislation (for the abolition of revenue intermediaries, for rent control and security of tenure), however tardy and shallow it may have been in implementation, brought in the state to the remotest corners of village society. With the advantage of numbers in electoral politics as hitherto backward groups get to capture state power, they are not too keen to weaken it or to give up the loaves and fishes of office and the elaborate network of patronage and subsidies that comes with it. ${ }^{3}$ This serves as a major political block to the (largely elite-driven) attempts at economic liberalization of recent years, as we will discuss later.

5. For a large federal democracy India, by constitutional design, differs from the classical case of US federalism in some essential features. Not merely is the federal government in India more powerful vis-a-vis the states in many respects (including the power to dismiss state governments in extreme cases and to reconstitute new states out of an existing state in response to movements for regional autonomy), but it has also more obligation, through mandated fiscal transfers (via the Finance Commission and the Planning Commission), to help out poor regions. In classical federalism the emphasis is on restraining the federal government through checks and balances, in India it is more on regional redistribution and political integration. Stepan (1999) has made a useful distinction between 'coming-together federalism' like the US, where previously sovereign polities gave up a part of their sovereignty for efficiency gains from resource pooling and a common market, and 'holding-together federalism' as in multinational democracies like India or Belgium or Spain, where compensating transfers keep the contending nationalities together and where economic integration of regional markets is a distant goal, yet incompletely unachieved even in more than 50 years of federalism.

Given these social and historical differences in the evolution of democracy in India its impact on inequality and poverty has been rather complex. In the history of western democracies extension of franchise has been associated with welfare measures for the poor. In the more recent data for a large number of countries cross-country regressions have found a positive association between democracy and some human development indicators ${ }^{4}$ (relevant largely for the poor) or incomes of the lowest quintile of income distribution. ${ }^{5}$ What has been the performance over time of the Indian democracy in terms of economic inequality and poverty? If we examine inequality in terms of the Gini coefficient there has not been much change overall. According to household consumer expenditure data collected by the National Sample Survey, during 1983 to 2000 
for example, rural inequality in consumption decreased a bit whereas urban inequality increased somewhat. Poverty has fallen significantly, though. In 1983 46 per cent of the population was below the Planning Commission poverty line whereas in 1999-2000 this figure was about 29 per cent. Despite this fall, India remains the largest single-country contributor to the pool of the world's extremely poor, illiterate people. Anti-poverty programs constitute a substantial part of the budgets of federal and state governments, but it is widely noted that a large part of them do not reach the real poor. The poverty figures are based on NSS consumption data and not data on income. Some fragmentary data on income suggest that the Gini coefficient for income distribution remains quite high, around 0.41 (and the Gini coefficient for asset distribution substantially higher). Some people contend that in the last decade or so the top 1 per cent of the population has become much richer, and their income or consumption is not captured in the usual survey data.

On the other hand, democracy has clearly brought about a kind of social revolution in India. It has spread out to the remote reaches of this far-flung country in ever-widening circles of political awareness and self-assertion of hitherto subordinate groups. These groups actually have increased faith in the efficacy of the political system and they vigorously participate in larger numbers in the electoral process. In the National Election Study ${ }^{6}$ carried out by the Centre for the Study of Developing Societies, the percentage of respondents who answered positively to the question, 'do you think your vote has effect on how things are run in this country?', went up between 1971 and 1996 from 48.4 per cent to 58.7 per cent for the total population, from 45.7 per cent to 57.6 per cent for 'backward caste' groups (designated as OBC in India), from 42.2 per cent to 60.3 per cent for the lowest castes (designated as scheduled castes), and 49.9 per cent to 60.3 per cent for Muslims (only later data can show if this figure has now changed for Muslims in view of the recent happenings in parts of the country).

Yet, this faith in the efficacy of the political system is very inadequately translated into concrete results on economic progress for the median member of the poor disadvantaged groups. Let us explore this particular disjuncture between economics and politics in India a bit further. The politicians are seldom penalised by the Indian electorate for endemic poverty; poverty is widely regarded among common people as a complex phenomenon with multiple causes, and they ascribe only limited responsibility to the government in this matter. In any case the measures of government performance are rather noisy, particularly in a world of illiteracy and low levels of civic organization and formal communication on public issues. As we have indicated before, a perceived slight in the speech of a political leader felt by a particular ethnic group will usually cause much more of an uproar than if the same leader's policy neglect keeps thousands of children severely malnourished in the same ethnic group. ${ }^{7}$ The same issue of group dignity 
comes up in the case of reservation of public sector jobs for backward groups which, as we have said before, fervently catches the public imagination of such groups, even though, objectively the overwhelming majority of the people in these groups have little chance of ever landing those jobs, as they and their children drop out of school in large numbers by the fifth grade. Even when these public job quotas mainly help the tiny elite in backward groups, as a symbol and a possible, though distant, object of aspiration for their children, they ostensibly serve a valuable function in attempts at group upliftment.

Particularly in north India there seems to be a preoccupation with symbolic victories among the emerging lower-caste political groups; as Hasan (2000) points out, with reference to BSP, a politically successful party of the oppressed in UP, these groups seem less concerned about changing the economic-structural constraints under which most people in their community live and toil. Perhaps this is just a matter of time. These social and political changes have come to north India rather late; in south India, where such changes have taken place several decades back, it may not be a coincidence that there has been a lot more effective performance in the matter of public expenditures on pro-poor projects like health, education, housing and drinking water. This reflects the fact that in south India there has been a long history of social movement against exclusion of lower castes from the public sphere, against their educational deprivation, etc. in a way more sustained and broad-based than in north India. One may also note that the upper caste opposition to social transformation is somewhat stronger in north India, as demographically upper castes constitute in general a somewhat larger percentage of the population than has been the case in most parts of south India. So new political victories of lower castes in north India get celebrated in the form of defiant symbols of social redemption and recognition aimed at solidifying their as yet tentative victories, rather than in committed attempts at changing the economic structure of deprivation.

From this major disjuncture between politics and economics in India let me now move on to the various kinds of disjuncture that have appeared in the Indian scene between the policy of economic reform and the on-going political and administrative processes. Economists often ignore these, and are surprised when things do not proceed in the way they want. In the last two decades, particularly since the early nineties, India has launched a widely-heralded process of economic reform with a view to unleashing the entrepreneurial forces from the shackles of the nightmarish controls and regulations that have hobbled the economy for years. Yet many commentators have noted our ways of lumbering, proceeding two steps forward, one step backward. We need to have a better understanding of why reform is so halting and hesitant, why there is no substantial and durable political constituency for reform (outside the small confines of India's metropolitan elite), why even the few supporters of reform 
underplay it at election time. In the rest of this lecture I shall point to ten different kinds of disjuncture that may be linked to this phenomenon.

1. Any process of sustained economic reform and investment requires a framework of long-term policy to which the government can credibly commit itself. But the political process in India seems to be moving in the opposite direction. While becoming more democratic and inclusive in terms of incorporating newer and hitherto subordinate groups, it is eroding away most of the structures of institutional insulation of long-run economic management decisions against the wheeling and dealing of day-to-day politics. There are very few assurances that commitments made by a government (or a leader) will be kept by successive ones, or even by itself under pressure. A political party that introduces some reforms is quick to oppose them when it is no longer in power.

2. With the extensive deregulation of the last two decades it was expected that corruption that is associated with the system of permits and licenses will decrease. There are no hard estimates, but by most anecdotal accounts corruption has, if anything, gone up in recent years. Although there may have been some decline in smuggling, black market in foreign exchange, or real estate. Some of the newer social groups coming to power are quite nonchalant in suggesting that all these years upper classes and castes have looted the system, now it is their turn. This has implications for the milking of the remaining obstructive regulations, particularly at the level of state governments (for example in matters of water and electricity connections to factories or enterprises, and in land acquisition and registration). As elections become more and more expensive the demands on business from the politician-regulator are unlikely to relent.

3. Much more than economic reform the major economic issue that captures public imagination, as we have noted before, is that of job reservation for an increasing number of 'backward' groups, which is accepted by all political parties. In the last decade of market reform more and more of the public sector job market has been carved up into protected niches. Cynics may even argue that the retreat of the state, implied by economic reform, is now more acceptable to the upper classes and castes, as the latter are losing their control over state power in the face of the emerging hordes of hitherto subordinate groups, and they are opting for greener pastures in the private sector and abroad. As these hitherto subordinate groups capture state power they are not likely to easily give up the lucrative benefits of office and the elaborate network of patronage distribution that goes with it. This is more acutely the case at the state government level where these groups are more secure in power. 
4. There have been few substantive reforms in the agricultural sector, and the non-agricultural informal sector has been hurt by the credit crunch. Yet these two sectors constitute 93 per cent of the total labor force. No wonder they are not enthused by the reforms carried out so far. In fact even organised farm lobbies (with few exceptions) have not been very active in demanding reforms of agricultural controls like those on storage and distribution and on domestic and foreign trade. They may be worried that the dismantling of the existing structure of food, fertilizer, water and electricity subsidies in exchange of receiving, say, international agricultural prices may be too complex and politically risky a deal. In any case the high administered procurement prices for grains have now eroded India's earlier (largely unexploited) competitive advantage in world grain markets.

5. Political power is shifting more to regional governments and regional parties, which makes national coordination on macro policy more difficult. For example, fiscal consolidation in general and a substantial reduction in the budget subsidies in particular are difficult when the national government depends on the support of powerful regional parties that assiduously nurse their parochial interest lobbies with a liberal use of subsidies (implicit or explicit). As the logic of economic reform and increased competition leads to increased regional inequality, it is not clear how the Indian federal system will resolve the tension between the demands of the better-off states for more competition and those of other states (which a politically weaker Centre can ill afford to ignore politically) for redistributive transfers. Can, for example, a coalition government at the Centre, dependent for its survival on the large number of MPs from weak states (like Bihar or UP), ignore their redistributive demands to compensate them for losing out in the interstate competition for private investment? It is also the case that a large number of entry taxes on goods imposed by governments even in otherwise leading states in economic reform (for example, Maharashtra, Tamil Nadu) are making the goal of reformers to unify an integrated all-India market that much more distant.

6. While the political power of regional governments is increasing, at the same time their fiscal dependence on the Centre is also increasing. (Between the middle 1950s to middle 1990s, the fraction of states' current expenditures financed by their own revenue sources declined from around 70 per cent to around 55 per cent). A significant part of the central transfers is discretionary (examples are the numerous central sector and centrally sponsored schemes); these and discretionary subsidized loans are often used by the Centre more for political influence in selected areas than for the cause of fiscal or financial reform or of poverty removal.

7. Reform would have been more popular if it was oriented to aspects of human development (education, health, child nutrition, drinking water, women's 
welfare and autonomy, etc.). Reformers usually are preoccupied with problems of the foreign trade regime, fiscal deficits, and the constraints on industrial investments in the factory sector, and they believe that once these are handled right, trickle-down will take care of the issues that concern the masses. In particular, the reformers have paid little attention to the crucial problems of governance in matters of achieving human development, which will be inexorably there even if trade, fiscal and industrial policy reforms were successful. Ravallion and Datt (2002) show from an analysis of household survey data across 15 states over 1960 to 1994 that non-farm growth is less effective in reducing poverty in states with poorer initial conditions in terms of rural development, human resources and land distribution. For example, nearly two-thirds of the difference between the elasticity of headcount poverty index to non-farm output for Bihar and Kerala is attributable to the latter's substantially higher initial literacy rate. If the administrative mechanism of delivery of public services in the area of human development remains seriously deficient, as it is today in most states, chances of constructing a minimum social safety net are low, and without such a safety net any large-scale program of economic reform will remain politically unsustainable, not surprisingly in a country where the lives of the overwhelming majority of the people are characterized by a brutal lack of economic security.

Of course, decentralization of governance which the 73rd and the 74th constitutional amendments in the early 1990s ushered in most of the country (around the same time as serious economic reforms were also launched) has raised hopes for better delivery of public services, sensitive to local needs. In some sense this is quite a landmark in administrative reforms. But so far the progress in this respect has been disappointing in most states, both in terms of actual devolution of authority and funds, and the outcome variables of services actually delivered. Let me just quote from one general evaluation, by Pal (2001): 'With some exceptions in Kerala, Madhya Pradesh, Tripura and West Bengal, nothing worthwhile has been devolved to the panchayats. The bureaucracy at all tiers of panchayats is holding the balance.' Note also that in Kerala and West Bengal decentralization with regular panchayat elections started long before the constitutional amendments. In many states not just the bureaucracy (which often has overlapping functions with the panchayats) has been reluctant to let go, the local MLAs, in order to protect their patronage turf, have hijacked the local electoral and administrative process (even in otherwise better-run states like Tamil Nadu). In Andhra Pradesh, a state supposedly at the forefront of economic reform, the Chief Minister is reportedly using information technology to further centralise (and personalise) the administrative process. Even in the relatively successful case of West Bengal the major role of panchayats has been in 
identifying beneficiaries of government programmes and the management and implementation of local infrastructure projects like roads and irrigation, funded by tied grants from the Central or state government. There is no serious involvement of the panchayat in the management or control of basic public services like primary education, public health and sanitation or in raising local resources. Of course, prior land reforms in Kerala and West Bengal have made the panchayats somewhat less prone to capture by the village landed oligarchy as compared to parts of north India.

8. Another potential link between economic reform and decentralization largely un-utilized in India relates to small-scale, particularly rural, industrialization. (In fact, rural non-farm employment grew at a much slower rate in the nineties than in the eighties). The Chinese success in the phenomenal growth in rural industries is often ascribed to decentralization, by which the Central and provincial governments gave 'positive' incentives to the local government-run village and township enterprises (by allowing them residual claimancy to the money they make) and 'negative' incentives to keep them on their toes (in the form of refusing to bail them out if they lose money in the intense competition with other such enterprises). In India decentralization is usually visualised only in terms of delivery of welfare services, not in terms of fostering local business development, and yet if this link could be established, economic reform would have been much more popular, as local informal-sector industries touch the lives of many more people than the corporate sector. A program of economic reform that involves curbing the petty tyranny and corruption of the small industry inspectors (who currently act as serious barriers to potential entry), encouraging micro-finance and marketing channels, and providing the 'positive' and 'negative' incentives of Chinese-style decentralization, has the potential of opening the floodgates of small-scale entrepreneurship in India. Examples of successful cooperative business development with the leadership of the local government, though rare in India, are not entirely absent. Take the case of the Manjeri municipality in the relatively backward district of Malappuram in north Kerala, with not much of a pre-existing industrial culture. In this area the municipal authorities, in collaboration with some NGOs and bankers, have succeeded in converting it into a booming hosiery manufacturing centre, after developing the necessary skills at the local level and the finance. This and other award-winning panchayats in Kerala dispel the common presupposition that civic bodies in the villages and small towns of India do not have the capability to take the leadership in developing and facilitating skill-based small-scale and medium-scale industries.

9. It is anomalous to expect reform to be carried out by an administrative setup that for many years has functioned as an inert, arbitrary, heavy- 
handed, often corrupt, uncoordinated, monolith. Economic reform is about competition and incentives, and a governmental machinery that does not itself allow them in its own internal organization is an unconvincing proponent or carrier of that message. Yet very few economists discuss the incentive and organizational issues of administrative reform as an integral part of the economic reform package. We have an administrative structure dominated by bureaucrats chosen on the basis of a generalist examination (rank in that early entry examination largely determines the career path of an officer no matter how well or ill suited s/he is in the various jobs $s /$ he is scuttled around, each for a brief sojourn), and promotions are largely seniority-based not merit or performance-based. There are no well-enforced norms and rules of work discipline, very few punishments for ineptitude or malfeasance, and there are strong disincentives to take bold, risky decisions. Whether one likes it or not, the government will remain quite important in our economy for many years to come, and it is difficult to discuss the implementation of economic reform without the necessary changes in public administration including incentive reforms, accompanied by changes in information systems, organizational structure, budgeting and accounting systems, task assignments, and staffing policies. In these matters there is a lot to learn from the (successes and failures of) innovative administrative reform experiments that have been carried out in many developing countries in the last decade or so.

10. Finally, in large parts of the country the judiciary (particular at the lower end) is almost completely clogged by the enormous backlog of cases and the legal system is largely paralysed by delay and corruption. Even more important, the institutional independence of the police and criminal justice system is regularly undermined by politicians of whichever is the ruling party. As result, the rule of law, which is as much the foundation stone of a regime of market reforms as of political democracy, is often sadly missing. (The N.N. Vohra Committee Report of a few years back, now shelved, clearly spelled out the nexus between politicians, bureaucrats, the mafia, and even some members of the judiciary.) This politicisation of police and the administrative system is also the institutional background of the state-abetted carnage in Gujarat last year. This shameful chapter of recent Indian history took place in a state which is supposed to be a leader in economic reforms, indicating an alarming disjuncture between politics and economics in India today.

But much more than hostility of certain religious groups is involved here; what is basically at stake is a political failure of the Indian state. In large parts of India sectarian interests are fishing in the troubled waters mainly caused by a failed state, when the state cannot deliver the essential services (health, 
education, a minimum safety net and the rule of law). When public schools, for example, do not deliver education to the poor, they sometimes are compelled to send their children to the schools run by Hindu fanatics or madrasas run by Muslim fanatics. Market reformers, instead of trying to organize the retreat of the state, should devote a large part of their energies to the cause of reform of the state machinery, to administrative and judicial reform to make the state more accountable to the common people, and to prevent the hijacking of the police and the criminal justice system by the politician-criminal nexus.

In this lecture I have started with a delineation of the different social and historical context of Indian democracy, compared to the West, how it adds complexity to its relation with problems of inequality and poverty. In this discussion I have underlined the various kinds of disjunctures that have appeared, and unless these are addressed not much reform or reduction of poverty and inequality will be sustainable, in spite of the many strides of undoubted social and economic progress the country has taken over the last five decades.

\section{References}

P. Bardhan (1984), The Political Economy of Development in India, Oxford University Press, with an expanded edition in 1998, New Delhi.

Z. Hasan (2000), 'Representation and Redistribution: The New Lower Caste Politics of North India', in F.R. Frankel et al. (eds), Transforming India: Social and Political Dynamics of Democracy, Oxford University Press, New Delhi.

M. Lundberg and L. Squire (1999), 'Growth and Inequality: Extracting the Lessons for Policymakers', Working Paper, World Bank, Washington D.C.

A. Mani and S.W. Mukand (2000), 'Democracy and the Politics of Visibility', Working Paper, Vanderbilt University.

M. Pal (2001), 'Documenting the Panchayat Raj', Economic and Political Weekly, 8 September.

A. Przeworski, M. Alvarez, J.A. Cheibub, and F. Limongi (2000), Democracy and Development: Political Institutions and Material Well-being in the World, 1950-1990, Cambridge University Press, Cambridge.

M. Ravallion and G, Datt (2002), 'Why Has Economic Growth been More Pro-poor in some States of India than Others?', Journal of Development Economics, August.

Y. Yadav (2000), ‘Understanding the Second Democratic Upsurge: Trends of Bahujan Participation in Electoral Politics in the 1990s', in F. Frankel, et al. (2000), Transforming India: Social and Political Dynamics of Democracy, Oxford University Press, New Delhi. 


\section{Endnotes}

${ }^{1}$ See Bardhan $(1984,1998)$.

${ }^{2}$ One of the early leaders who carried in him the tension between individual and group rights was Ambedkar himself, a formidable constitutional lawyer concerned with individual liberty, but who was also a major spokesman of an oppressed caste group.

${ }^{3}$ In some sense this is familiar in the history of American municipal politics in big cities when one after another hitherto disadvantaged ethnic group captured the city administration and distributed patronage.

${ }^{4}$ See A. Przeworski, M. Alvarez, J.A. Cheibub, and F. Limongi (2000).

${ }^{5}$ See M. Lundberg and L. Squire (1999).

${ }^{6}$ See Yadav (2000).

${ }^{7}$ For a formal analysis of the role of visibility in influencing government resource allocation across multiple public goods in an electoral framework, see Mani and Mukand (2000). 